\title{
Boron metasomatism in the Brabant Massif (Belgium): Geochemical and petrographical evidence of Devonian tourmalinite pebbles
}

\section{Corteel* \& P. De Paepe}

Universiteit Gent, Laboratorium voor Mineralogie \& Petrologie, Krijgslaan 281 -

S8, B-9000 Gent, Belgium; e-mail: Cedric.Corteel@rug.ac.be

* Corresponding author

Manuscript received: December 2000; accepted: December 2002

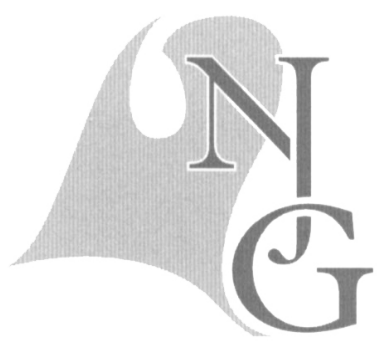

\begin{abstract}
New petrographical and geochemical evidence of tourmalinite pebbles from two Lower and three Middle Devonian formations from Belgium is presented. Petrography, REE, transition metal and microprobe data of the studied rocks suggest it are (meta)sediment-derived tourmalinites formed by boron metasomatism (and hydrothermal brecciation) in an intrusive setting. Tourmaline mineralizations within eastern Avalonia are known in south-east Ireland, the English Lake District and East Anglia. Based on previously suggested relations between Early Palaeozoic igneous activity in last two mentioned regions and the Brabant Massif, it is presumed that the Brabant Massif also underwent granite-related tourmalinization and that this was the source of the studied pebbles. Petrologic differences between pebbles found in Middle Devonian formations and pebbles from Lower Devonian formations, suggest that fluid circulation occurred on a regional scale, possibly extending into the Stavelot massif.
\end{abstract}

Keywords: Avalonia, Devonian, pebbles, provenance, tourmalinite, Brabant Massif

\section{Introduction}

In Belgium tourmalinites occur as pebbles in various Lower and Middle Devonian conglomerates. They were intensively studied in the decades following their discovery by de la Vallée-Poussin \& Renard in 1877. Hypotheses about their source remained very speculative (e.g. Stainier 1889; Anten 1921; Macar 1948). Later, interest in these tourmalinites waned due to their complicated petrography and the complete absence of field relations. Up to now only Fieremans \& De Paepe (1982) reported chemical analyses. This paper discusses preliminary petrographical and geochemical evidence of the Belgian tourmalinites (Corteel 2000 a \& b).

Two Lower and three Middle Devonian formations were sampled for tourmalinites. The Lower Devonian Lochkovian Fooz Formation crops out along the northern border of the Dinant Allochthon (Godefroid et al. 1994; Fig. 1), while the Burnot Formation is present along the northern and north-eastern border of the Dinant Allochthon. The latter formation is presumed to be latest Emsian (Godefroid et al. 1994).

In the Middle Devonian, tourmalinites occur in the Eifelian Rivière Formation, on the northern border of the Dinant Allochthon and the southern border of the Namur Par-autochthon (Bultynck et al. 1991). The Late Eifelian Vicht Formation crops out along the northern border of the Stavelot Massif, where several conglomeratic levels contain tourmalinite pebbles (Kasig \& Neumann-Mahlkau 1969). The Eifelian to Givetian Pépinster Formation, (Hance et al. 1996), occasionally contains tourmalinites.

\section{Analytical methods}

To determine the major element contents our samples were melted using the method of Medlin et al. 


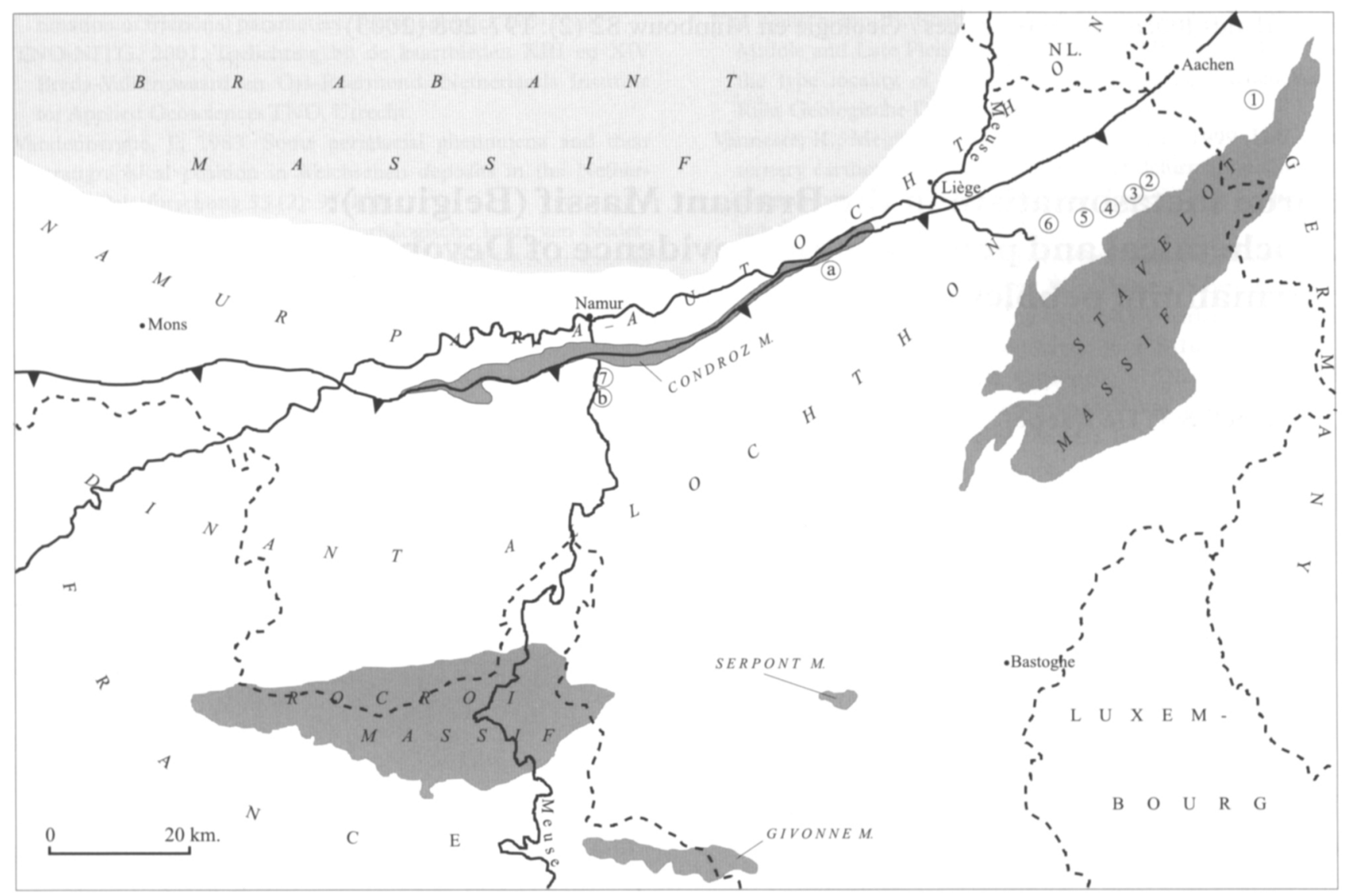

Fig. 1. Map of southern Belgium with main tectonic units and sample localities. 'Caledonides' in dark are cropping out, while the lighter shaded Brabant massif is mainly subcrop. The thrust zone is the Variscan Front. Sample localities: Lower Devonian: a) Ombret (Fooz Formation), b) Rivière (Burnot Formation); Middle Devonian: 1) Vicht (Vicht Formation), 2) Eupen (Vicht Formation), 3) Membach (Vicht Formation), 4) Goé (Vicht and Pépinster Formations), 5) Stembert (Vicht Formation), 6) Pépinster (Vicht Formation), 7 Tailfer (Rivière Formation).

(1969), except for B and F of which solutions were prepared following the procedure of Dietz (1975). The latter elements were detected with a Vitatron Universal Photometer, UPM and a WTW Microprocessor $\mathrm{pH}$-meter equipped with an ionselective electrode respectively, while all other major elements were measured using a Perkin-Elmer 2380 Atomic Absorption Spectrophotometer. Solutions for determining trace elements were prepared by dissolving melts of $500 \mathrm{mg}$ sample and $1.5 \mathrm{mg}$ lithium-metaborate in $5 \mathrm{ml} \mathrm{HNO}_{3}(65 \%)$ and $1 \mathrm{ml} \mathrm{HF}(48 \%)$. $\mathrm{Rb}$ was detected with AES. And $\mathrm{Cr}, \mathrm{Co}, \mathrm{Ni}, \mathrm{Cu}$ and $\mathrm{Zn}$ with AAS; the remaining trace elements were determined with an Elan 5000 Perkin-Elmer ICP-MS.

About 100 tourmalines in C-coated thin-sections from five selected samples were analysed with WDX on a CAMECA Camebax SX50 Microprobe at an electric potential of $15 \mathrm{kV}$, a beam current of $20 \mathrm{nA}$ and a beam diameter between 1 and $5 \mu \mathrm{m}$ with a surface resolution of 4 to $5 \mu \mathrm{m}$. In each measurement $\mathrm{B}$, $\mathrm{F}, \mathrm{Na}, \mathrm{Mg}, \mathrm{Al}, \mathrm{Si}, \mathrm{K}, \mathrm{Ca}, \mathrm{Ti}, \mathrm{Cr}, \mathrm{Mn}$ and $\mathrm{Fe}$ were determined and missing weight percentages were assumed to be $\mathrm{H}_{2} \mathrm{O}$. Accuracy of boron measurements were calibrated against a borosilicate glass standard (NIST 93a). Results yielded systematically lower concentrations with a maximum deviation of $2 \%$.

\section{Results}

Thin-section microscopy of the pebbles allowed the recognition of three petrographical groups, which all consist mainly of tourmaline and quartz with at maximum $10 \%$ accessory minerals, mostly rutile and some zircon and iron oxides. Occasionally muscovite, sphene, chloritized biotite and fibrous chlorite are also encountered. In all three distinguished types veins occur, mainly made up by quartz, but tourmaline and to a lesser extent accessory minerals, are also present. Pebbles belonging to the first group display a poikiloblastic texture, in which the host crystals are large quartz grains. They enclose several grains of greenish tourmalines and some accessory minerals (rutile), which contitute about $10 \%$ of the rock volume. One of these specimens shows a banded pattern, caused by an alternation of tourmaline-rich and tourmalinepoor zones. 


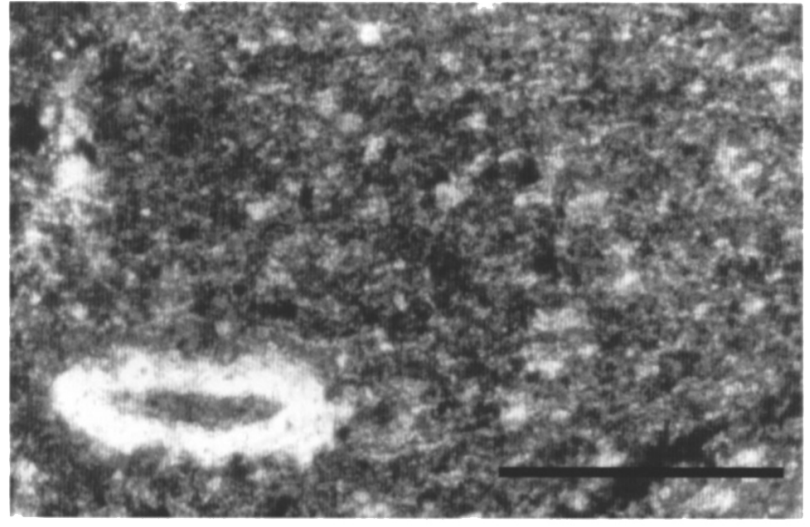

Fig. 2. Photomicrograph under parallel polarisors of a tourmalinite of the type 3 texture illustrating the typical fine grained 'structureless' texture of tourmaline and quartz. The darker grains are mainly rutile and some opaques. Note in the lower left corner the remarkable occurrence of a flattened annular shaped quartz zone. This phenomenon was encountered in several samples of this type but we were unable to recognise or explain it. Scale bar is $500 \mu \mathrm{m}$.

The second group contains samples which exhibit a brecciated texture. They consist of tourmaline and fragments of tourmalinites lying in a groundmass of equigranular quartz grains. In parts of these samples where only tourmaline or aggregates of it occur, a poikiloblastic appearance is present. As in some rocks of group 1, tourmaline exhibits a large variation of colours and shapes and is regularly zoned. Tourmalinite fragments strongly vary in size $(100 \mu \mathrm{m}$ to several $\mathrm{mm}$ ) and show different textures, some of which resemble group 3 .

Group 3 represents about $85 \%$ of our samples. They have a fine to medium grained texture made up of intergrown tourmalines and irregular quartz spots (Fig. 2). Tourmaline is the most important component ( $45-85 \%$ of the rock volume). It is predominantly green and mainly anhedral, although euhedral crystals, often lath-like and occasionally forming radial aggregates occur too. Concentric zonations are not uncommon in larger grains.

Nearly half the tourmalinites of this group display a banded pattern, even macroscopically visible in a few pebbles. It results from an alternation of tourmalinerich zones and zones dominated by equigranular quartz. Some samples of this group show a mudrockappearance with a matrix consisting of the finegrained tourmaline-rich texture typical for this group. This matrix encloses clastic quartz grains, constituting about $15 \%$. In a number of veins, small euhedral tourmalines lie enclosed in larger quartz crystals causing a poikiloblastic texture.

With the exception of one partly poikiloblastic rock of the Rivière Formation all breccias and poikiloblastic textures among our pebbles were sampled at the Lower Devonian outcrops that yielded tourmalinites, situated on the northern side of the Dinant Allochthon. Group-3 samples with a mudrock appearance were only encountered in Middle Devonian conglomerates, nearly exclusively in the Vicht Formation, along the northern border of the Stavelot Massif.

Table 1 shows the concentrations of major and minor components of 8 selected tourmalinites. Table 2 shows some representative microprobe analyses of tourmaline. Structural formulas are based on the formula $\mathrm{XY}_{3} \mathrm{Z}_{6}\left(\mathrm{BO}_{3}\right)_{3} \mathrm{Si}_{6} \mathrm{O}_{18}(\mathrm{OH}, \mathrm{F})_{4}$, modified from the formula proposed by Hawthorne \& Henry (1999). Normalisation is based on $31 \mathrm{O}$-atoms. Si-deficiency is compensated by $\mathrm{Al}$ in tetrahedral position $(\mathrm{T})$ and full occupancy of the $Z$-site was sought, adding Fe in case of an $\mathrm{Al}$ deficit. Remaining $\mathrm{Al}$ and/or $\mathrm{Fe}$ are put in the Y-position together with $\mathrm{Mg}, \mathrm{Ti}, \mathrm{Cr}$ and $\mathrm{Mn}$. $\mathrm{Ca}, \mathrm{Na}$ and $\mathrm{K}$ are restricted to the $\mathrm{X}$-site. In the tourmaline classification of Hawthorne \& Henry (1999),

Table 1 . Whole rock analyses in weight $\%$ of the oxides of 8 tourmalinites; standard deviations are $2 \%$.

\begin{tabular}{|c|c|c|c|c|c|c|c|c|}
\hline Sample & FO.1 & PGM.2a & BC. 2 & TLC. $2 \mathrm{a}$ & VE.3 & VM.4 & VM.5 & VP.4 \\
\hline $\mathrm{SiO} 2$ & 45.73 & 55.57 & 38.96 & 60.06 & 58.78 & 65.89 & 74.29 & 63.65 \\
\hline $\mathrm{A} 12 \mathrm{O} 3$ & 22.18 & 22.33 & 28.96 & 19.98 & 22.56 & 16.68 & 13.14 & 18.83 \\
\hline $\mathrm{Fe} 2 \mathrm{O} 3$ & 10.86 & 8.13 & 8.71 & 8.15 & 6.38 & 3.85 & 3.86 & 7.05 \\
\hline $\mathrm{MgO}$ & 4.65 & 1.44 & 5.95 & 1.54 & 2.20 & 3.86 & 1.57 & 1.71 \\
\hline $\mathrm{CaO}$ & 0.73 & 0.24 & 0.52 & 0.22 & 0.40 & 0.39 & 0.18 & 0.27 \\
\hline $\mathrm{Na} 2 \mathrm{O}$ & 1.61 & 0.79 & 1.94 & 0.91 & 0.87 & 1.08 & 0.51 & 0.88 \\
\hline $\mathrm{K} 2 \mathrm{O}$ & 0.03 & 0.04 & 0.07 & 0.02 & 0.53 & 0.05 & 0.10 & 0.06 \\
\hline $\mathrm{MnO}$ & 0.07 & 0.10 & 0.05 & 0.05 & 0.10 & 0.03 & 0.02 & 0.05 \\
\hline $\mathrm{TiO} 2$ & 0.80 & 1.07 & 1.10 & 0.95 & 1.01 & 0.68 & 0.74 & 0.84 \\
\hline $\mathrm{B} 2 \mathrm{O} 3$ & 7.66 & 6.51 & 8.71 & 6.04 & 5.91 & 5.09 & 4.00 & 5.08 \\
\hline $\mathbf{F}$ & 0.15 & 0.06 & 0.08 & 0.13 & 0.06 & 0.17 & 0.07 & 0.23 \\
\hline $\mathrm{H} 2 \mathrm{O}-$ & 0.25 & 0.22 & 0.29 & 0.29 & 0.29 & 0.21 & 0.25 & 0.18 \\
\hline $\mathrm{H} 2 \mathrm{O}+$ & 2.51 & 1.48 & 2.38 & 1.15 & 1.45 & 1.69 & 1.13 & 1.38 \\
\hline total & 97.21 & 97.97 & 97.69 & 99.47 & 100.51 & 99.65 & 99.84 & 100.20 \\
\hline
\end{tabular}


Table 2. Major element compositions in weight $\%$ of the oxides of 12 tourmaline grains and their calculated formulas based on 31 O-atoms.

\begin{tabular}{|c|c|c|c|c|c|c|c|c|c|c|c|c|}
\hline Sample & FO1.13a3 & FO1.13b' & FO1.4c & BC1.30a & BC1.24-2 & aVM1a.4a & VM1a.25b & TLC4a.5a1 & TLC4a.5a2 & TLC4a.24a & VM6b.1b & VM6b.17a \\
\hline $\mathrm{Na} 2 \mathrm{O}$ & 1.95 & 2.36 & 1.04 & 1.53 & 0.96 & 2.19 & 0.93 & 1.99 & 1.82 & 2.14 & 1.02 & 1.63 \\
\hline $\mathrm{K} 2 \mathrm{O}$ & 0.00 & 0.02 & 0.19 & 0.05 & 0.01 & 0.00 & 0.00 & 0.02 & 0.01 & 0.01 & 0.04 & 0.02 \\
\hline $\mathrm{SiO} 2$ & 37.12 & 36.64 & 36.69 & 36.25 & 36.51 & 36.13 & 35.96 & 36.92 & 36.78 & 36.59 & 35.39 & 35.86 \\
\hline $\mathrm{Al} 2 \mathrm{O} 3$ & 31.34 & 30.83 & 33.24 & 33.25 & 34.79 & 31.49 & 35.55 & 32.36 & 31.33 & 32.12 & 34.97 & 35.14 \\
\hline $\mathrm{FeO}$ & 6.06 & 9.99 & 9.09 & 10.98 & 11.32 & 9.05 & 9.02 & 6.76 & 5.83 & 8.52 & 13.23 & 10.27 \\
\hline $\mathrm{MnO}$ & 0.00 & 0.05 & 0.06 & 0.09 & 0.07 & 0.01 & 0.03 & 0.00 & 0.02 & 0.02 & 0.07 & 0.01 \\
\hline $\mathrm{MgO}$ & 8.31 & 6.18 & 5.39 & 3.41 & 2.10 & 6.31 & 3.48 & 7.27 & 8.13 & 6.31 & 1.38 & 3.31 \\
\hline $\mathrm{CaO}$ & 0.81 & 0.21 & 0.38 & 0.41 & 0.06 & 0.59 & 0.46 & 0.72 & 1.40 & 0.32 & 0.21 & 0.33 \\
\hline $\mathrm{TiO} 2$ & 0.63 & 0.22 & 0.14 & 0.70 & 0.20 & 0.63 & 0.30 & 0.35 & 0.94 & 0.23 & 0.10 & 0.21 \\
\hline $\mathrm{Cr} 2 \mathrm{O}_{3}$ & 0.03 & 0.00 & 0.01 & 0.07 & 0.00 & 0.03 & 0.04 & 0.06 & 0.04 & 0.06 & 0.02 & 0.02 \\
\hline $\mathrm{B} 2 \mathrm{O} 3$ & 9.41 & 9.38 & 9.55 & 9.01 & 8.58 & 9.44 & 8.86 & 9.31 & 8.71 & 9.26 & 9.04 & 9.03 \\
\hline $\mathrm{F}$ & 0.15 & 0.07 & 0.13 & 0.15 & 0.02 & 0.31 & 0.10 & 0.24 & 0.29 & 0.05 & 0.10 & 0.17 \\
\hline $\mathrm{H} 2 \mathrm{O}$ & 4.21 & 4.07 & 4.08 & 4.10 & 5.40 & 3.81 & 5.28 & 4.01 & 4.69 & 4.37 & 4.42 & 3.99 \\
\hline Total & 100.00 & 100.00 & 100.01 & 100.00 & 100.00 & 100.00 & 100.00 & 100.01 & 100.00 & 100.00 & 100.00 & 100.00 \\
\hline \multicolumn{13}{|l|}{ Formula } \\
\hline Si & 6.066 & 6.096 & 6.038 & 6.035 & 5.997 & 5.997 & 5.859 & 6.053 & 6.008 & 6.031 & 5.909 & 5.948 \\
\hline $\mathrm{Al}$ (tetr.) & 0 & 0 & 0 & 0 & 0.003 & 0.003 & 0.141 & 0 & 0 & 0 & 0.091 & 0.052 \\
\hline B & 2.655 & 2.695 & 2.712 & 2.589 & 2.432 & 2.706 & 2.493 & 2.634 & 2.454 & 2.636 & 2.606 & 2.586 \\
\hline $\mathrm{Al}(Z)$ & 6 & 6 & 6 & 6 & 6 & 6 & 6 & 6 & 6 & 6 & 6 & 6 \\
\hline $\mathrm{Fe}(\mathrm{Z})$ & 0 & 0 & 0 & 0 & 0 & 0 & 0 & 0 & 0 & 0 & 0 & 0 \\
\hline $\mathrm{Al}(\mathrm{Y})$ & 0.036 & 0.046 & 0.448 & 0.525 & 0.733 & 0.156 & 0.684 & 0.252 & 0.031 & 0.24 & 0.79 & 0.816 \\
\hline $\mathrm{Fe}(\mathrm{Y})$ & 0.828 & 1.39 & 1.252 & 1.529 & 1.554 & 1.257 & 1.229 & 0.927 & 0.797 & 1.174 & 1.847 & 1.425 \\
\hline $\mathrm{Mg}$ & 2.024 & 1.532 & 1.322 & 0.847 & 0.514 & 1.562 & 0.845 & 1.777 & 1.978 & 1.55 & 0.343 & 0.819 \\
\hline $\mathrm{Ti}$ & 0.077 & 0.027 & 0.018 & 0.088 & 0.024 & 0.079 & 0.036 & 0.044 & 0.116 & 0.028 & 0.012 & 0.026 \\
\hline $\mathrm{Cr}$ & 0.003 & 0 & 0.002 & 0.009 & 0 & 0.004 & 0.005 & 0.007 & 0.005 & 0.007 & 0.002 & 0.002 \\
\hline $\mathrm{Mn}$ & 0 & 0.007 & 0.009 & 0.012 & 0.009 & 0.001 & 0.004 & 0 & 0.003 & 0.003 & 0.009 & 0.001 \\
\hline Y tot & 2.969 & 3.003 & 3.05 & 3.01 & 2.835 & 3.059 & 2.804 & 3.006 & 2.929 & 3.002 & 3.004 & 3.09 \\
\hline $\mathrm{Ca}$ & 0.141 & 0.037 & 0.067 & 0.073 & 0.01 & 0.105 & 0.081 & 0.126 & 0.245 & 0.057 & 0.038 & 0.059 \\
\hline $\mathrm{Na}$ & 0.618 & 0.76 & 0.332 & 0.494 & 0.305 & 0.703 & 0.292 & 0.632 & 0.577 & 0.684 & 0.331 & 0.525 \\
\hline $\mathrm{K}$ & 0 & 0.004 & 0.041 & 0.01 & 0.002 & 0 & 0 & 0.004 & 0.003 & 0.003 & 0.009 & 0.004 \\
\hline Xtot & 0.758 & 0.801 & 0.44 & 0.577 & 0.317 & 0.809 & 0.373 & 0.762 & 0.825 & 0.744 & 0.378 & 0.588 \\
\hline $\mathrm{OH}$ & 4.588 & 4.513 & 4.484 & 4.556 & 5.913 & 4.215 & 5.739 & 4.387 & 5.111 & 4.805 & 4.926 & 4.419 \\
\hline $\mathbf{F}$ & 0.076 & 0.037 & 0.068 & 0.078 & 0.008 & 0.161 & 0.05 & 0.125 & 0.15 & 0.027 & 0.053 & 0.09 \\
\hline
\end{tabular}

most measured grains fall in the groups of alkali tourmaline, based on the X-site constituents. Further classification based on the other sites cannot be made, because $\mathrm{Li}$ content, $\mathrm{O}^{2-} / \mathrm{OH}$ and $\mathrm{He}^{3+} / \mathrm{Fe}^{2+}$ ratios cannot be determined with the used technique.

Fig. 3 displays a negative correlation between $\mathrm{Fe}$ and $\mathrm{Mg}$, reflecting the reciprocal substitutions of these elements along the schorl-dravite series in the analysed grains. The sum of these elements also exhibits a negative interdependence to the $\mathrm{Al}$ contents (Fig. 4), meaning that a deficit of $\mathrm{Fe}+\mathrm{Mg}$ is compensated by $\mathrm{Al}^{3+} / \mathrm{Li}^{+}$in the Y-position. According to the vector representation in Fig. 3, however, such elbaïte substitutions appear to be of minor importance in our samples. Although the microprobe analyses were performed on tourmalines from the three petrographical groups we distinguished, the results do not reflect this division. Considering the stratigraphical distribution of the samples it appears that tourmalines in tourmalinites from the Vicht Formation (VM.1a and VM.6b) are more aluminous than tourmalines in the other analysed pebbles (Figs 3 \& 4).

Microprobe measurements also allow comparison of the composition of tourmalines from the fine grained tourmalinite mass and tourmalinite-fragments with that of other textural environments such as tourmalines in veins or dispersed in the larger quartz minerals. Major element abundances reveal no difference between tourmalines from different textural frameworks.

Nevertheless the relation between $\mathrm{Fe}$ and $\mathrm{Mg}$ can differ within one specimen according to the context of the concerned grains (Fig. 5). We notice e.g. for the analyses of tourmalines in veins (Fig. 5a) of the sample TLC.4a and to a lesser extent FO.1, a more negative correlation between both elements than in other measured crystals within the same thin-sections (Fig. 5b).

In Fig. 6 the microprobe results are plotted in variation diagrams for tourmalines proposed by Henry 


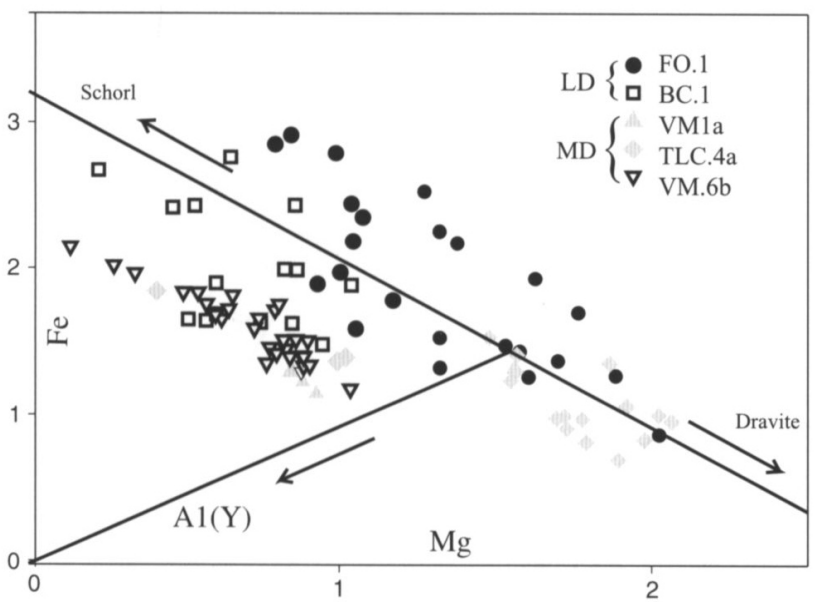

Fig. 3. Number of atoms of Fe vs. Mg per formula unit (based on microprobe measurements) of tourmalines in five different samples. LD: Lower Devonian samples; MD: Middle Devonian samples. Vectors from London \& Manning (1995).

and Guidotti (1985). These diagrams reveal granitoid origins for the analysed tourmalines in samples BC.2 and VM. $6 \mathrm{~b}$ and a (meta)sedimentary nature for those of sample TLC.4a, while tourmalines from FO.1 plot
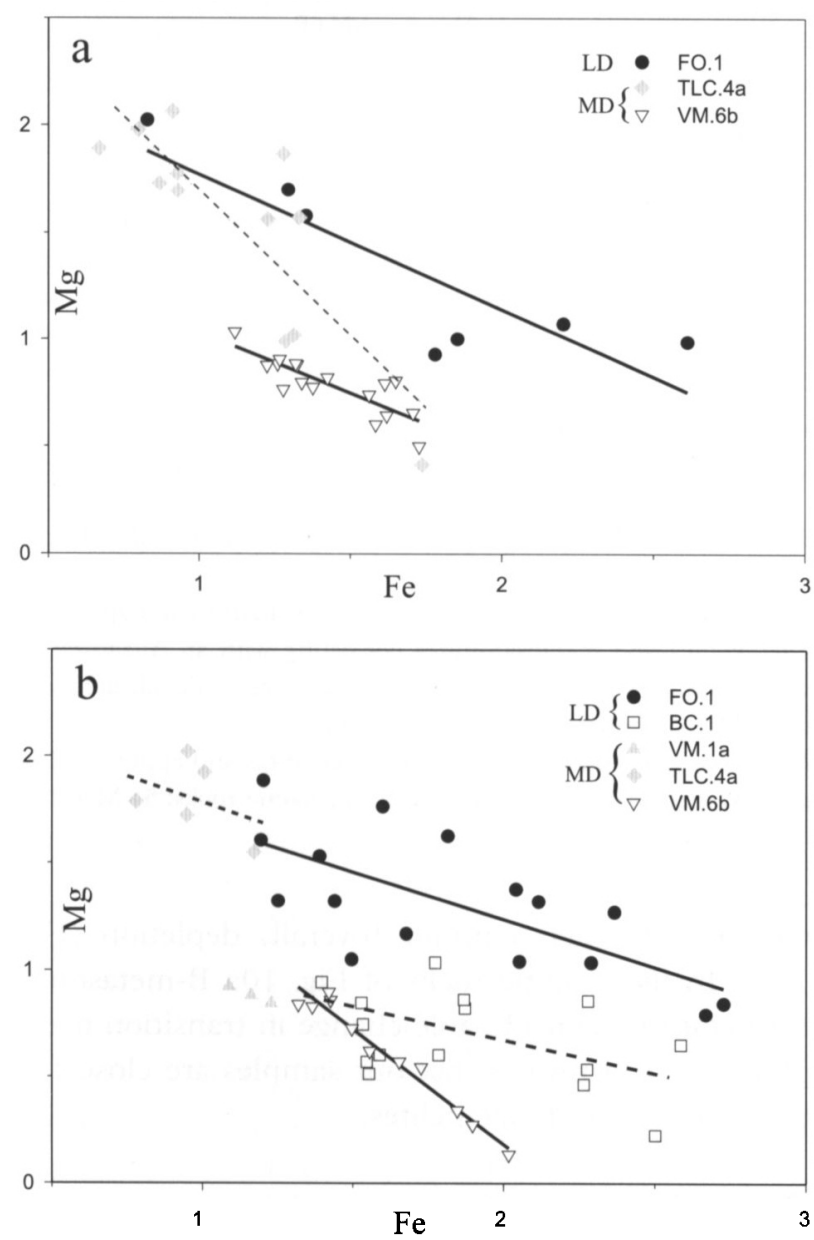

Fig. 5. Numbers of atoms of $\mathrm{Mg}$ vs. Fe per formula unit (based on microprobe measurements) of tourmalines in veins (a - upper Figure) and in other textural surroundings ( $b$ - lower Figure). LD: Lower Devonian samples; MD: Middle Devonian samples.

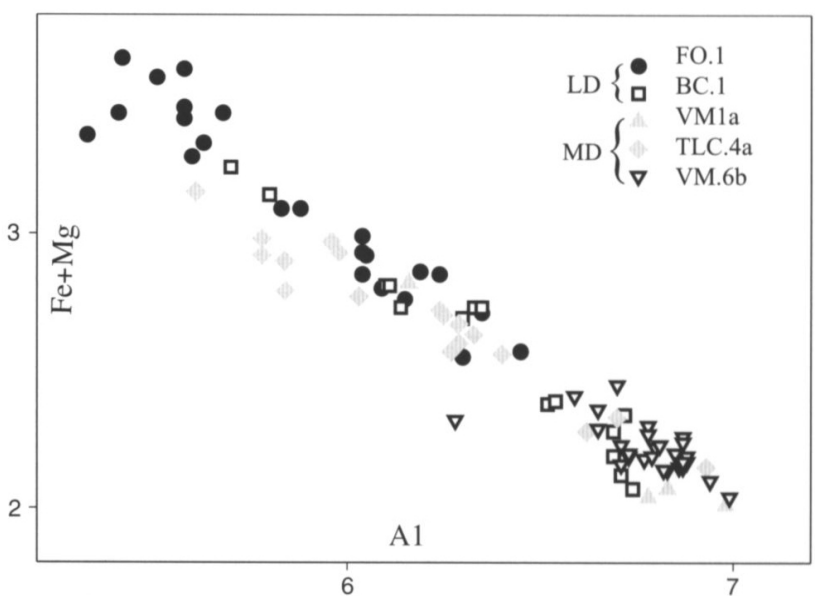

Fig. 4. Numbers of atoms of $\mathrm{Fe}+\mathrm{Mg}$ vs. Al per formula unit (based on microprobe measurements) of tourmalines in five different samples. LD: Lower Devonian samples; MD: Middle Devonian samples.

in both these areas. For VM.1a the two diagrams are inconsistent. Variations among tourmalines within one sample occur but can again not be related to the textural context of the grains. Within zoned grains however there is a tendency towards more Mg-rich external zones and higher $\mathrm{Fe}$-contents in the cores (Fig. 7a). Measurements along traverses in zoned tourmalines (Fig. $7 \mathrm{~b}$ ) show that the composition between core and rim does not vary equally in all samples.

Trace element abundances (in ppm) are given in table 3. According to North American Shale Composite (NASC) normalised plots of rare earth element (REE) concentrations our samples belong to three different groups (Fig. 8), of which only one coincides with one of the categories we distinguished based on petrographic characteristics. It concerns the sample FO.1, which has a brecciated texture and exhibits an uncommon REE-pattern. Samples of petrographic groups 1 and 3 show two different types of REE curvature. The first one falls quite close to the normalising values, suggesting a shaly nature for the concerning pebbles while a second type resembles this pattern but displays a minor depletion of the heavy rare earth elements (HREEs) for some samples and a considerable depletion of the light rare earth elements (LREEs) for all of them. The higher $\mathrm{SiO}_{2}$-contents of these rocks (Table 1) probably cause the minor overall depletion but are unable to explain the supplementary LREE depletion. NASC-normalised multielement diagrams of incompatible elements all show a depletion of the elements to the left of the graphs (Fig. 9).

Since those are easily dissolvable in water this suggests a hydrothermal activity during the tourmalinization of the samples. Similar patterns in all three 

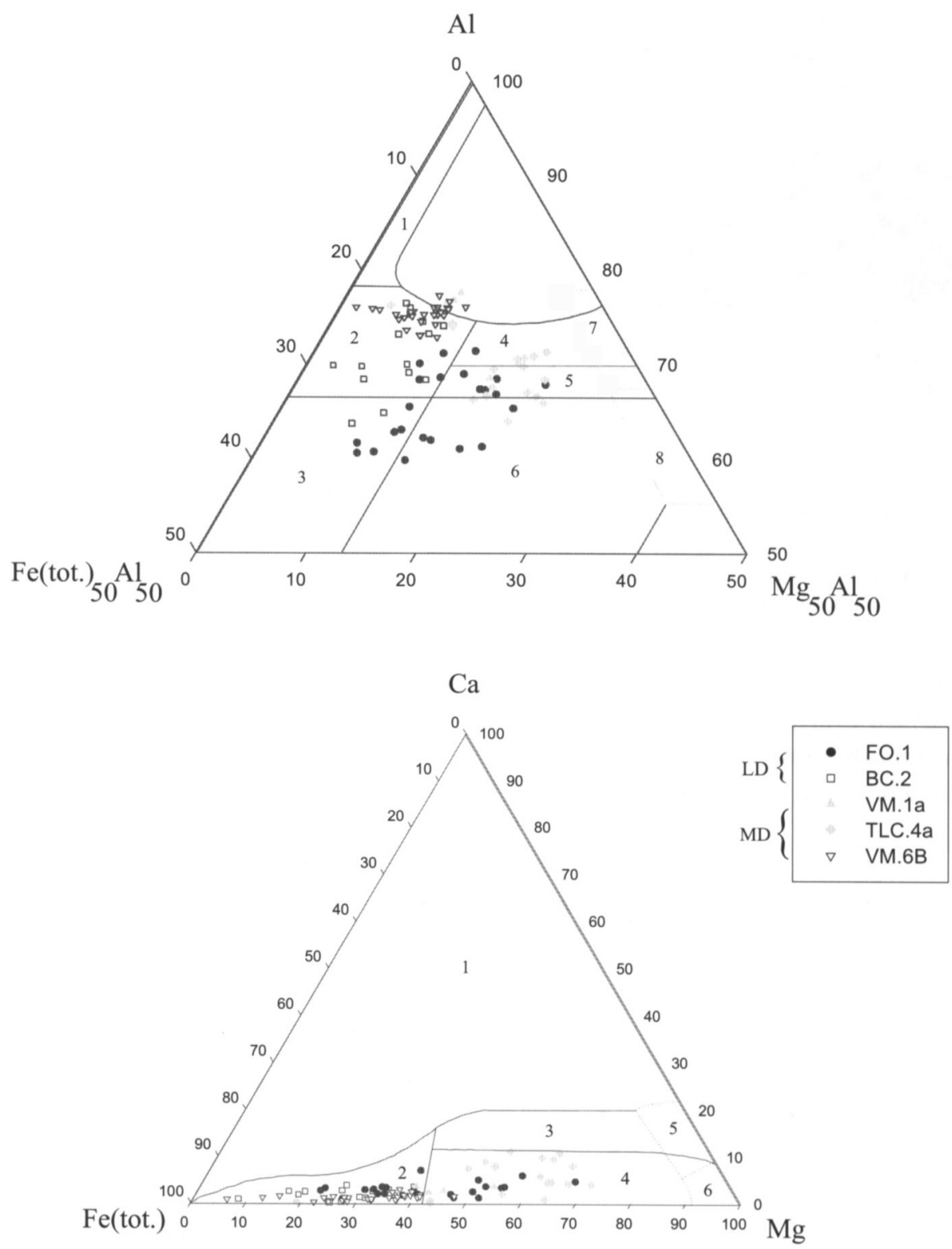

Fig. 6. Ternary diagrams of element concentrations (in molecular proportions) of tourmalines analysed with microprobe. Fields after Henry \& Guidotti (1985). LD: Lower Devonian samples; MD: Middle Devonian samples.

a - upper Figure: Al-Fe-Mg: 1) Li-rich granitoid pegmatites and aplites; 2) Li-poor granitoids and their associated pegmatites and aplites; 3) $\mathrm{Fe}^{3+}$-rich quartz-tourmaline rocks (hydrothermally altered granites); 4) Metapelites and metapsammites coexisting with an Al-saturating phase; 5) Metapelites and metapsammites not coexisting with an Al-saturating phase; 6) $\mathrm{Fe}^{3+}$-rich quartz-tourmaline rocks, calc-silicate rocks and metapelites; 7) Low-Ca metaultramafics and CR, V-rich metasediments; 8) Metacarbonates and metapyroxenites.

b- lower Figure: Ca-Fe-Mg: 1) Li-rich granitoid pegmatites and aplites; 2) Li-poor granitoids and associated pegmatites and aplites; 3) Carich metapelites, metapsammites and calc-silicate rocks; 4) Ca-poor metapelites, metapsammites and quartz-tourmaline rocks; 5) Metacarbonates; 6) Metaultramafics.

groups for $\mathrm{Zr}$, Hf and Ti might be caused by the minerals zircon and rutile, which occur in comparable amounts in the analysed specimens and contain a considerable number of these atoms.

Although most transition metals are generally classified as compatible elements, we compared transition metal plots of unaltered rocks with their tourmalinised equivalents (Figures $9 \mathrm{a}-\mathrm{c}$ ) of data from three different settings available in literature. Concerning the metapelitic rock types represented we notice in one case a relatively unchanged situation (Fig. 10c) and in the other a minor (overall) depletion (Fig. 10b). In the granitic rocks of Fig. 10a B-metasomatism causes a considerable change in transition metal plot. Fig. 10d reveals that our samples are closest to the tourmalinised metapelites.

\section{Discussion}

\section{Precursors}

Considering the tourmalinization circumstances of 

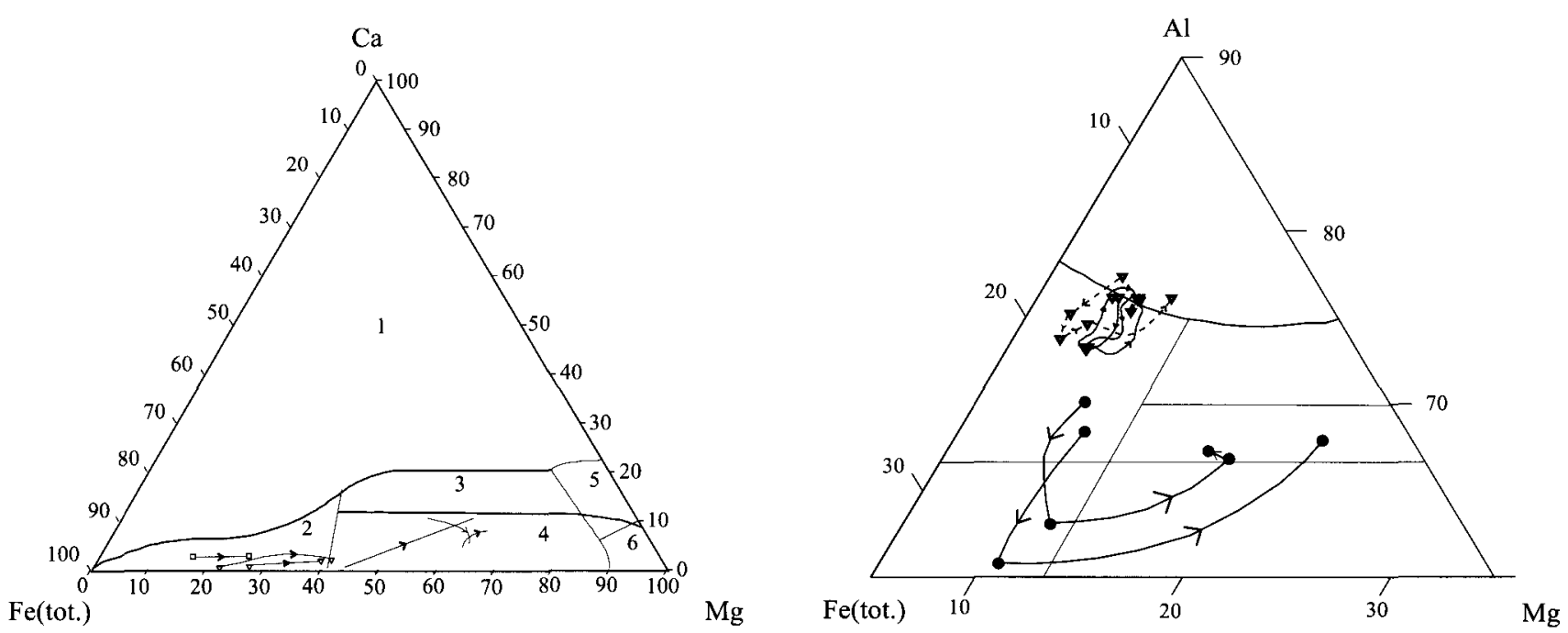

Fig. 7. Ternary diagrams of element concentrations (in molecular proportions) of zoned tourmalines analysed with microprobe. Fields (after Henry \& Guidotti, 1985) and symbols as in Fig. 6.

a - upper Figure: $\mathrm{Ca}-\mathrm{Fe}-\mathrm{Mg}$ analyses of cores and rims, arrows pointing from core to rim.

$\mathrm{b}$ - lower Figure: $\mathrm{Al}-\mathrm{Fe}-\mathrm{Mg}$ traverses through zoned grains, arrows pointing from core to rim.

our samples we notice the occurrence of zoned tourmalines. Many authors interpret their presence in tourmalinites as an indication for hydrothermal activity (e.g. Benvenuti et al. 1989), which is also supported by the low concentrations of the easily dissolvable elements (Fig. 9). Furthermore Bajwah et al. (1995) measured strong depletions of $\mathrm{K}, \mathrm{Rb}$ and $\mathrm{Ba}$ in tourmalinized granites relative to the unaltered intrusion and attributed these depletions for the two last mentioned elements to a metasomatic proces. Since the data of Fig. 9 refer to whole rock-analyses this implies that the hydrothermal solutions penetrated complete-

Table 3. Trace element contents in ppm of 8 tourmalinites. Standard deviations for $\mathrm{Cr}$ to $\mathrm{Rb}$ are $2 \%$, others are rounded off according to their standard deviation. $\mathrm{La}_{\mathrm{n}}$ an $\mathrm{Yb}_{\mathrm{n}}$ are normalised to the $\mathrm{C} 1$ chondrite of Sun \& Mc.Donough (1989).

\begin{tabular}{|c|c|c|c|c|c|c|c|c|}
\hline Sample & FO.1 & PGM.2a & BC.2 & TLC. $2 a$ & VE.3 & VM.4 & VM.5 & VP.4 \\
\hline $\mathrm{Cr}$ & 119 & 136 & 140 & 117 & 134 & 141 & 98 & 97 \\
\hline Co & 22 & 11 & 20 & 7 & 6 & 9 & 7 & 5 \\
\hline $\mathrm{Ni}$ & 62 & 38 & 101 & 33 & 41 & 43 & 28 & 9 \\
\hline $\mathrm{Cu}$ & 24 & 9 & 8 & 11 & 9 & 7 & 7 & 12 \\
\hline $\mathrm{Zn}$ & 33 & 54 & 19 & 32 & 32 & 16 & 21 & 16 \\
\hline $\mathrm{Rb}$ & 11 & 6 & 8 & 6 & 25 & 4 & 8 & 6 \\
\hline $\mathrm{Y}$ & 144.2 & 31.6 & 18.9 & 26.2 & 40.1 & 19.2 & 17.7 & 30.1 \\
\hline $\mathrm{Zr}$ & 107.6 & 124.7 & 167.8 & 119.9 & 121.6 & 119.6 & 234.6 & 142.9 \\
\hline $\mathrm{Nb}$ & 11.3 & 17.7 & 12.6 & 18.4 & 18.6 & 16.2 & 14.4 & 16.5 \\
\hline Cs & $<0.1$ & $<0.1$ & $<0.1$ & $<0.1$ & $<0.1$ & $<0.1$ & $<0.1$ & $<0.1$ \\
\hline $\mathrm{Ba}$ & 10 & 11 & 33 & 9 & 104 & 18 & 36 & 21 \\
\hline $\mathrm{La}$ & 5.5 & 53.5 & 32.9 & 8.8 & 56.1 & 10.8 & 5.8 & 16.2 \\
\hline $\mathrm{Ce}$ & 16.7 & 117.1 & 82.6 & 23.9 & 126.4 & 34.4 & 20.8 & 35.4 \\
\hline Pr & 2.9 & 12.5 & 9.0 & 2.8 & 14.0 & 4.2 & 2.4 & 4.0 \\
\hline $\mathrm{Nd}$ & 14.1 & 43.8 & 34.1 & 11.2 & 52.4 & 17.3 & 9.7 & 15.2 \\
\hline $\mathrm{Sm}$ & 7.15 & 7.32 & 6.37 & 3.05 & 10.31 & 3.89 & 2.26 & 3.30 \\
\hline $\mathrm{Eu}$ & 2.64 & 1.53 & 0.95 & 0.77 & 1.87 & 0.80 & 0.49 & 1.03 \\
\hline $\mathrm{Tb}$ & 3.76 & 1.06 & 0.77 & 0.79 & 1.58 & 0.69 & 0.53 & 0.78 \\
\hline Dy & 22.82 & 5.66 & 3.72 & 4.88 & 8.24 & 3.56 & 3.20 & 4.97 \\
\hline Ho & 4.53 & 1.16 & 0.72 & 0.96 & 1.55 & 0.68 & 0.68 & 1.09 \\
\hline $\mathrm{Er}$ & 12.48 & 3.29 & 2.32 & 2.98 & 4.15 & 1.99 & 2.10 & 3.29 \\
\hline $\mathrm{Tm}$ & 1.76 & 0.47 & 0.38 & 0.44 & 0.58 & 0.26 & 0.34 & 0.47 \\
\hline$Y b$ & 11.27 & 3.35 & 3.32 & 3.33 & 3.96 & 2.17 & 2.68 & 3.33 \\
\hline $\mathrm{Lu}$ & 1.66 & 0.45 & 0.55 & 0.43 & 0.50 & 0.32 & 0.40 & 0.48 \\
\hline Hf & 2.4 & 3.2 & 3.9 & 3.0 & 3.2 & 3.3 & 5.9 & 3.7 \\
\hline $\mathrm{Ta}$ & 0.8 & 1.3 & 1.0 & 1.2 & 1.3 & 0.9 & 1.0 & 1.2 \\
\hline$(\mathrm{La} / \mathrm{Yb}) \mathrm{n}$ & 0.35 & 11.46 & 7.09 & 1.90 & 10.16 & 3.57 & 1.54 & 3.49 \\
\hline
\end{tabular}




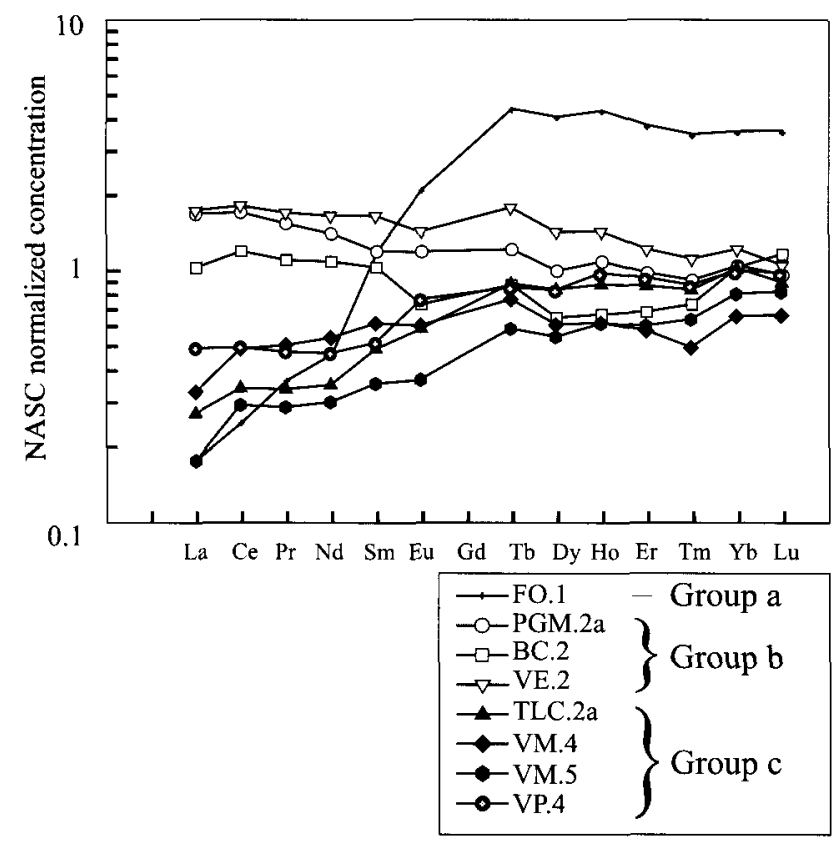

Fig. 8. REE plot of 8 selected tourmalinites, normalised to the North American Shale Composite (NASC) values of Gromet et al. (1984). Samples marked with an $\left(^{\star}\right)$ are from Lower Devonian formations, others from Middle Devonian formations.

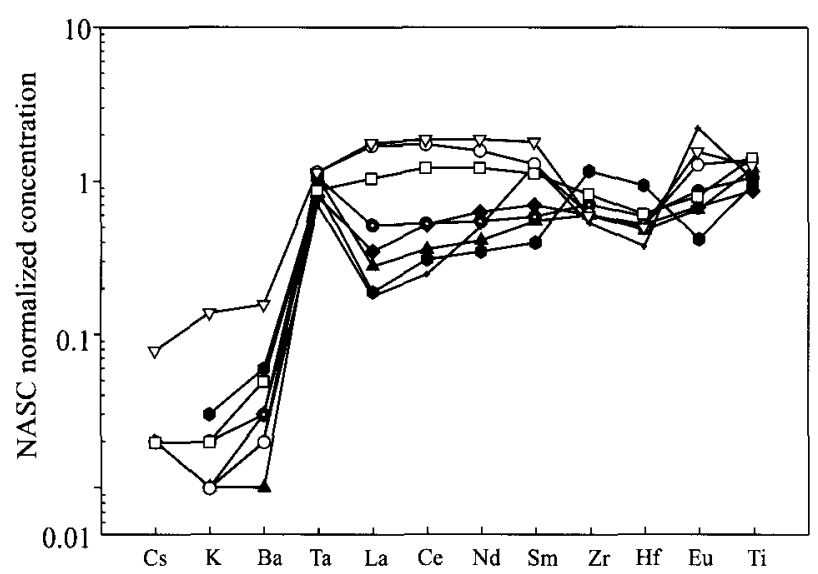

Fig. 9. Multi-element diagram of 8 selected tourmalinites normalised to the NASC values of Gromet et al. (1984). Symbols as in Fig. 8.

ly into the rocks instead of just along the veins, where most zoned tourmalines occur.

The banded pattern in pebbles from groups $1 \& 2$ suggests a sedimentary precursor (London \& Manning, 1995). Because REEs are generally considered relatively immobile during hydrothermal activity they should be examined first when trying to discover the precursors of the studied tourmalinites. Since Slack et al. (1993) demonstrated that REE abundances from metasediments can remain largely unchanged during tourmalinisation, the three samples close to the normalising values of the NASC in Fig. 8 indicate a sedimentary nature of the parent material. Regarding

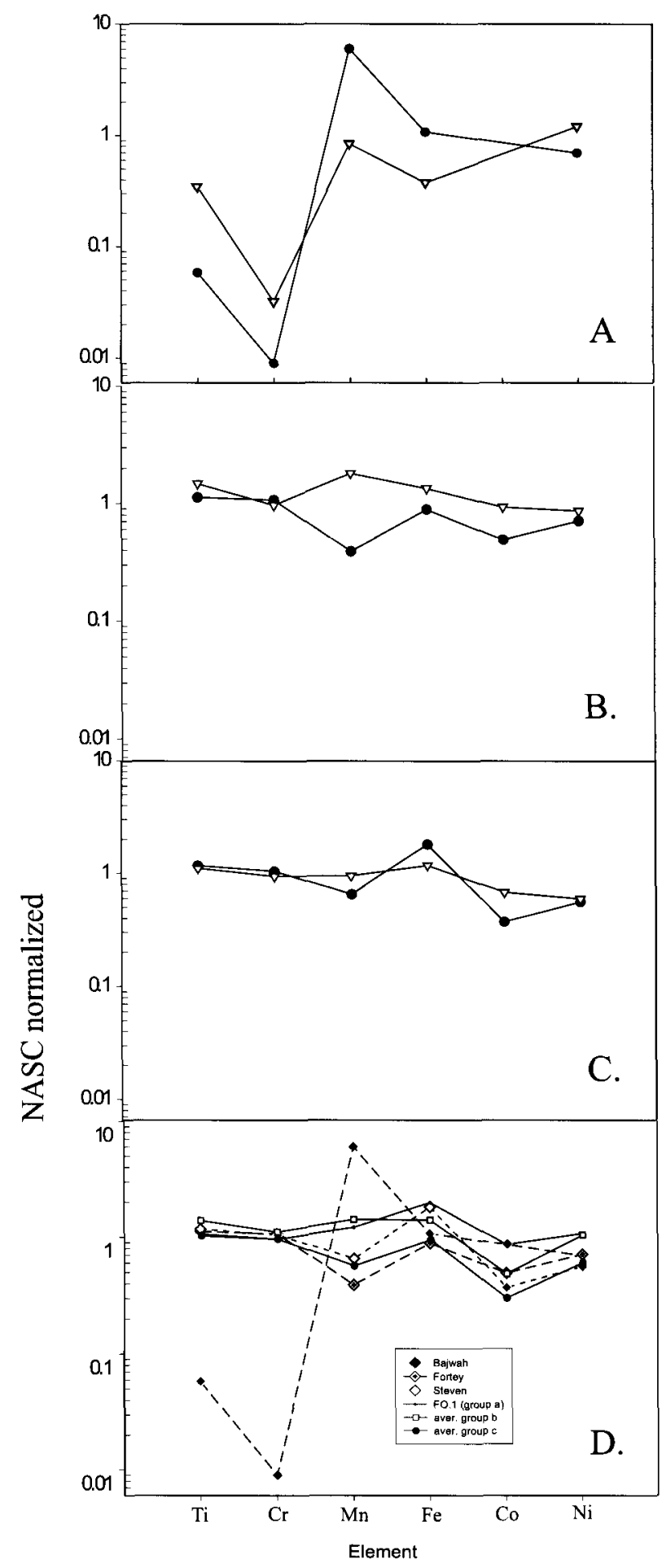

Fig. 10. $a-c)$ Transition metal plots of tourmalinites (full circles) and their unaltered precursors (open triangles), normalised to the NASC values of Gromet et al. (1984). Unaltered precursors: a) granite, b) slightly metamorphosed pelites, c) metapelites. Data from: a) Bajwah et al. (1995), b) Fortey \& Cooper (1986), c) Steven \& Moore (1995). d) Analogous plots as in Figures a-c, representing the tourmalinites of Figures a-c and averages of the three sample types distinguished in the REE and multi-element plots.

their petrography, we can assume that the four samples which exhibit a LREE depletion (Fig. 8), derive from an analogous parent material as these three 
samples. The gradually increasing depletion of the LREE with decreasing atomic number is probably due to a longer exposure to hydrothermal processes. Slack et al. (1996) reported that longer tourmalinization times are able to deplete selectively the LREEs and thus create a difference in REE fractionation values, as we observe in these two groups of samples (Table 3).

While the REE pattern of the analysed breccia (FO.1) is unusual, its transition-metal plot on the other hand does match the pattern of the other analysed pebbles (Fig. 10d). Considering that tourmalinization of (meta)sediments only poorly affects transition metal contents (Figures $9 \mathrm{~b} \& \mathrm{c}$ ), this implies a (meta)sedimentary precursor for this rock. The REE pattern of this sample (Fig. 8) should then be the result of LREE depletion and HREE enrichment. Haas et al. (1995) concluded that REE might be fractionated during hydrothermal processes due to different complexation of LREE and HREE in the same solution. Of course, this supposition remains speculative, since it means that in this sample the REEs - generally considered as relatively immobile - should have migrated strongly while the transition metals, more easily dissolvable, should have remained largely immobile. A possible explanation for this contradictory behaviour of both groups of elements is the presence of a complexing agent which selectively dissolved the REEs and not the transition metals, because the solubility of REEs (e.g. Bach \& Irber 1998; Lewis et al. 1998) and transition metals as well (Gallup 1998) appears to depend upon complexation.

According to London \& Manning (1995) the major element geochemistry of a metasomatic tourmaline is largely determined by its precursor rather than by the tourmalinizing fluid. The major element relations in Figures 2 and 3 however are often encountered in tourmalinites originating in very different settings (e.g. Michailidis 1998; Pesquera \& Velasco 1997) and thus provide little specific information about the original context of our samples. The results in the diagrams of Henry \& Guidotti (1985, Fig. 6), developed to determine tourmaline provenance, do not confirm completely the conclusions drawn from the petrographic and trace-element data because they reveal a granitoid component for some of the analysed tourmaline. Since many authors (e.g. Jiang et al., 1998) mention that the determining factor of tourmalinite geochemistry depends upon water/rock ratios one could expect compositional differences between grains from different textural environments. There is, however, no such relation and therefore we interpret the granitoid component in Fig. 6 as a geochemical overprint of the tourmalinizing agent.
Local model

The possibility of a change in major element composition due to B-metasomatism is supported by the inconsistency between Figs $6 \mathrm{a} \& 6 \mathrm{~b}$ for some grains in the samples VM.1a and FO.1. This indicates that the geochemistry of these grains reflects both the original sedimentary composition and the overprint of the fluid composition, because they plot in the granitoid field in one plot, and in a (meta) sedimentary field in the other. On the other hand, two analyses of a petrographically anomalous grain, unaffected by by tourmalinization (VM1a,4a, Table 2), plot in the (meta)sedimentary field in both diagrams. This shows that the tourmaline grains only partially inherit the host-rock composition.

Because we postulated that the parent rocks were (meta)sediments, the hydrothermal solution should have been relatively enriched in Fe since its influence in Fig. 6 is reflected in a shift from metasedimentary to more Fe-rich fields. Because many authors (e.g. Jiang et al. 1998) contribute high Fe-contents in hydrothermal fluids to an intrusive origin this conclusion reveals a granitoid nature for the tourmalinizing agent of these samples. Moreover, a negative inter-dependence between $\mathrm{Fe}$ and $\mathrm{Mg}$, as in Fig. 5a, is interpreted by Cavaretta and Puxeddu (1990) as an indication for a granitoid origin of the metasomatic fluid. The increase in $\mathrm{Mg}$-content accompanied by the $\mathrm{Fe}$ decrease from core to rim (Fig. 7a) provides complementary evidence for this assumption because such a variation might reflect a late-stage infiltration of nonmagmatic water in a plutonic hydrothermal system (Cavaretta and Puxeddu 1990).

The occurrence of a few hydrothermal breccias among our samples and the nature of the tourmalinizing agent imply tourmalinization by a granitic fluid. An analogous model has been applied by Cooper et al. (1988) to explain the metasomatism and mineralisation in the Crummock Water aureole. The hydrothermal solution circulated along a vein network, afterwards crystallised as poikiloblastic textures, and penetrated from there into the country rocks, which were intensively tourmalinized, with retention of a number of their sedimentary characteristics. This model also explains the difference in REE behaviour during tourmalinization between the hydrothermal breccia and the other analysed samples, because it implies much higher water/rock ratios in the brecciated parts than for the surrounding rocks.

Possibly the samples from the Vicht Formation tourmalinised further away from the intrusion since pebbles from this formation are clearly more aluminous than other group three samples (Figs $2 \& 3$ ) and 
tourmalinites showing the appearance of mudrocks occcur nearly exclusively in the Vicht Formation. These observations reflect the precursors of these tourmalinites to be more aluminous and coarser grained than those from other samples and thus support the assumption that they were derived from a different stratigraphic position or even another area.

\section{Regional setting}

According to Steemans (1989) the north-western source for the Belgian Lower Devonian deposits is the Brabant Massif, in which no evidence for B-metasomatism has hitherto been recorded. Recent field observations of the Burnot Formation (Corteel 2000b) demonstrated a fluviatile deltaic nature of the deposits from this formation and the roundness of the tourmalinite pebbles in these conglomerates reveal that regions at considerable distance from the place of deposition are possible sources. Palaeogeographic reconstructions of Early Devonian times (Ziegler 1982) indicate that the whole area to the north, north-east and east of the Brabant Massif was exposed and might have applied material via fluviatile transport. Given the generally accepted palaeocurrents the source has to be found presumably in an area belonging to Eastern Avalonia. Tourmalinites within this microcontinent occur in south-east Ireland (e.g. McArdle et al. 1989) and the English Lake District (e.g. Fortey \& Cooper 1986). Both of them are associated with Early Devonian intrusive activity (O'Connor et al. 1989 and Cooper et al. 1988). Noteworthy are also some minor tourmaline mineralisations encountered in drill cores in East Anglia (Tim Pharaoh, pers. comm.). According to currently applied plate tectonic reconstructions (e.g. McKerrow \& Cocks 1995), Ordovician to Devonian magmatic activity in south-east Ireland originated in the same tectonic environment as the Lake District and East Anglia, although McConnell \& Morris (1997) mention that the exact relationship between south-east Ireland and the Lake District has yet to be clarified. Also in the Brabant Massif there was some magmatic activity during Early Palaeozoic times (e.g. André \& Deutsch 1986). Pharaoh et al. (1991) proposed that the volcanics in the Brabant Massif formed part of an arc extending from Belgium via the southern North Sea and East Anglia towards the Lake District. The presence of tourmaline mineralisations in Southeast Ireland, the Lake District and East Anglia suggests that B-metasomatism was likely to occur in other areas on the northern edge of Avalonia where similar magmatism developed in response to the closure of the Tornquist Sea. In this case the Brabant Massif is of course the most probable source given its proximity to the place of deposition. This assumption is supported by the presence of a presumed batholith (e.g. Hennebert 1994; De Vos 1997, Chacksfield et al. 1993) underlying the Brabant Massif, which could have provided the tourmalinising hydrothermal solution.

By Mid Devonian times a regressive phase had allowed the southern border of the Old Red Continent to shift slightly to the south causing the area of the Stavelot Massif to form a part of that microcontinent (Kasig \& Neumann-Mahlkau 1969). This exposed other zones to erosion, which led Kennan (1983) to propose the Stavelot Massif as a source for the Belgian tourmalinites examined by Fieremans \& De Paepe (1982). Given our assumption that pebbles from the Middle Devonian Vicht Formation derive from another area in comparison to other examined tourmalinites, this might indeed be possible.

\section{Conclusions}

Petrography, REE patterns and transition metal plots reveal a sedimentary precursor for the analysed samples. Hydrothermal activity during tourmalinization can be deduced from the occurrence of zoned tourmalines and depletion of some easily dissolvable elements and LREE. Negative correlations between $\mathrm{Fe}$ and $\mathrm{Mg}$ for tourmalines in veins together with other microprobe results, suggest a granitoid origin for the tourmalinising agent. Considering these observations and the three petrographical groups we propose a tourmalinization through intense metasomatic activity by an intrusive fluid extending over a considerable distance into the countryrocks as a local model for the tourmalinization of the studied pebbles.

The source area of the (older) Belgian tourmalinites probably lies in eastern Avalonia, where tourmaline mineralisations have been recorded. Based on previously suggested relations between some of these regions with other areas on the northern edge of Avalonia (Pharaoh et al. 1991), we presume that graniterelated tourmalinization also occurred in some of these other areas, where magmatic activity developed due to the closure of the Tornquist Sea. In this respect the Brabant Massif is the most probable source, taking into account the inferred batholith underlying it and its proximity to the place of deposition (e.g. Hennebert 1994; De Vos 1997, Chacksfield et al. 1993). The (different) tourmalinite pebbles in Middle Devonian formations, might derive from different stratigraphic levels, but also other areas, such as the Stavelot Massif. 


\section{Acknowledgements}

C. Corteel would like to thank J. Verniers (Ghent University, Belgium) and L. André (RMMA, Belgium) for critical discussions on the subject and J. Van Hende (Ghent University) for performing the chemical analyses. We are also grateful to L. Moens (Ghent University) for cooperation on the ICP-MS analyses. T. Pharaoh and N. Fortey of the BGS (UK), J. Samuelsson (Université Rennes I, France) J. Verniers and L. Andre are thanked for reviewing the original manuscript. Finally we wish to acknowledge the comments of the reviewers.

\section{References}

Andre, L. \& Deutsch, S., 1986. Magmatic ${ }^{87} \mathrm{Sr} /{ }^{86} \mathrm{Sr}$ relicts in hydrothermally altered quartz diorites (Brabant Massif, Belgium) and the role of epidote as a Sr filter. Contributions to Mineralogy and Petrology 92: 104-112.

Anten, J., 1921. Sur l'origine des roches tourmalinifères du poudingue d'Ombret. Annales de la Société géologique de Belgique 45: $B$ 92-93.

Bach, W. \& Irber, W., 1998. Rare earth element mobility in the oceanic lower sheeted dyke complex: evidence from geochemical data and leaching experiments. Chemical Geology 151: 309326.

Bajwah, Z.U., White, A.J.R., Kwak, T.A.P. \& Price, R.C., 1995. The Renison Granite, Northwestern Tasmania: A petrological, geochemical and fluid inclusion study of hydrothermal alteration. Economic Geology 90: 1663-1675.

Benvenuti, M., Lattanza, P. \& Tanelli, G., 1989. Tourmalinite-associated $\mathrm{Pb}-\mathrm{Zn}-\mathrm{Ag}$ mineralization at Bottino, Apuane Alps, Italy: Geologic setting, mineral textures, and sulfide chemistry. Economic Geology 84: 1277-1292.

Bultynck, P., Coen-aubert, M., Dejonghe, L., Godefroid, J., Hance, L., Lacroix, D., Preat, A., Stainier, P., Steemans, P., Streel, M. \& Tourneur, F., 1991. Les formations du Dévonien Moyen de la Belgique. Toelichtende verhandelingen voor de geologische en mijnkaarten van België, 30. Ministerie van Economische Zaken (Brussel).

Cavarretta, G. \& Puxeddu, M., 1990. Schorl-dravite-ferridravite tourmalines deposited by hydrothermal magmatic fluids during early evolution of the Larderello geothermal field, Italy. Economic Geology 85: 1236-1251.

Chacksfield B.C., Devos, W., Dhooge, L., Dusar, M., Lee, M.K., Poitevin, C., Royles, C.P. \& Verniers, J., 1993. A new look at Belgian aeromagnetic and gravity-data through image-based display and integrated modeling techniques. Geological Magazine 130: 583-591.

Cooper, D.C., Lee, M.K., Fortey, A.H., Cooper, A.H., Rundle, C.C., Webb, B.C. \& Allen, P.M., 1988. The Crummock Water aureole: a zone of metasomatism and source of ore metals in the English Lake District. Journal of the Geological Society, London 145: 523-540.

Corteel, C. 2000a. Petrology of tourmalinite pebbles in Devonian conglomerates from Belgium: a preliminary study towards characterisation of eroded Caledonides. In: Abstracts volume of the GEOSCIENCE 2000, 17-20 April 2000, Manchester, UK

Corteel, C. 2000b. Boron-metasomatism in the Brabant Massif (Belgium)? Evidence from the Lower/Middle Devonian Burnot
Formation. In: Abstracts volume of the joint meeting of the EUROPROBE (TESZ) and PACE projects, 16-23 September 2000, Zakopane, Poland.

De La Vallee Poussin, C. \& Renard, A. F., 1877. Note sur un fragment de roche tourmalinifère du poudingue de Bousalle. Bulletin de l'Académie royale de Belgique 43, sér. 2: 359-372.

De Vos, W., 1997. Influence of the granitic batholith of Flanders on Acadian and later deformation (Brabant Massif, Belgium). Aardkundige Mededelingen 8: 49-52.

Dietz, F., 1975. Die Borkonzentration in Wässern als ein Indikator der Gewässerbelastung. GWF Wasser Abwasser 116: 301-308.

Fieremans, M. \& De Paepe, P., 1982. Genesis of tourmalinites from Belgium: petrographical and chemical evidence. Mineralogical Magazine 46: 95-102.

Fortey, N.J. \& Cooper, D.C., 1986. Tourmalinization in the Skiddaw Group around Crummock Water, English Lake District. Mineralogical Magazine 50: 17-26.

Gallup, D.L., 1998. Geochemistry of geothermal fluids and well scales, and potential for mineral recovery. Ore geology reviews 12: 225-236.

Godefroid, J., Blieck, A., Bultynck, P., Dejonghe, L., Gerrienne, P., Hance, L., Meilliez, F., Stainier, P. \& Steemans, P., 1994. Les formations du Dévonien Inférieur du Massif de la Vesdre, de la Fenêtre de Theux et du Synclinorium de Dinant (Belgique, France). Toelichtende verhandelingen voor de geologische en mijnkaarten van België, 38. Ministerie van Economische Zaken (Brussel).

Gromet, L.P., Dymek, R.F., Haskin, L.A. \& Korotev, R.L., 1984. The 'North American shale composite': Its compilation, major and trace element characteristics. Geochimica et Cosmochimica Acta 48: 2469-2482.

Haas, J.R., Shock, E. L. \& Sassani, D.C., 1995. Rare earth elements in hydrothermal systems: Estimates of standard partial molal thermodynamic properties of aqueous complexes of the rare earth elements at high pressures and temperatures. Geochimica et Cosmochimica Acta 59: 4329-4350.

Hance, L., Dejonghe, L., Fairon-Demaret, M. \& Steemans, P., 1996. La Formation de Pépinster dans le Synclinorium de Verviers, entre Pépinster et Eupen (Belgique) - contexte structural et stratigraphique Annales de la Société géologique de Belgique 117: 75-93.

Hawthorne, F.C. \& Henry, D.C. 1999. Classification of the minerals of the tourmaline group. European Journal of Mineralogy 11:201-215.

Hennebert, M., 1994 Rôle possible des structures profondes du Massif Cambro-Silurien du Brabant dans l'évolution des bassins sédimentaires Post-Calédoniens (Belgique et Nord de la France). Annales de la Société géologique de Belgique 116:147162.

Henry, D. J. \& Guidotti, C.V., 1985. Tourmaline as a petrogenetic indicator mineral: an example from the staurolite-grade metapelites of NW Maine. American Mineralogist 70: 1-15

Jiang, S., Palmer, M.R., Slack, J. F. \& Shaw, D. R., 1998. Paragenesis and chemistry of multistage tourmaline formation in the Sullivan $\mathrm{Pb}-\mathrm{Zn}-\mathrm{Ag}$ deposit, British Columbia. Economic Geology 93: 47-67.

Kasig, W. \& Neumann-Mahlkau, P., 1969. Die Entwicklung des Eifeliums in Old-Red-Fazies zur Riff-Fazies im Givetium und Unteren Frasnium am Nordrand des Hohen Venns (BelgienDeutschland). Geologische Mitteilungen 8: 327-388.

Kennan, P.S., 1983. Tourmalinites from Belgium and from SE Ireland - a discussion (short communication). Mineralogical Magazine 47: 236-238.

Lewis, A.J., Komninou, A., Yardley, B.W.D. \& Palmer, M. R., 1998. Rare earth element speciation in geothermal fluids from Yellow- 
stone National Park, Wyoming, USA. Geochimica et Cosmochimica Acta 62: 657-663.

London, D. \& Manning, D.A.C., 1995. Chemical variation and significance of tourmaline from Southwest England. Economic Geology 90: 495-519.

Macar, P., 1948. Nombreux cailloux de tourmalinite dans un banc d'arkose du Gedinnien, à Ovifat (Sourbrodt). Annales de la Société géologique de Belgique 71: 247-257.

Mcardle, P., Fitzell, M., Oosterom, M.G., O'Connor, P.J. \& Kennan, P.S., 1989. Tourmalinite as a potential host rock for gold in the Caledonides of southeast Ireland. Mineralium Deposita 24: 154-159.

McConnell, B. \& Morris, J. 1997. Initiation of Iapetus subduction under Irish Avalonia. Geological Magazine 134: 213-218.

McKerrow, W.S. \& Cocks, L.R.M. 1995. The use of biogeography in the terrane assembly of the Variscan belt of Europe. Studia geophysica et geodaetica 39: 269-275.

Medlin, J.H. \& Bodkin, J.B., 1969. Atomic absorption analysis of silicates employing $\mathrm{LiBO}_{2}$ fusion. Atomic Absorption Newsletter 8: $25-29$.

Michailidis, K.M., 1998. Tourmaline concentrations in metasedimentary rocks of the Efkarpia-Gerakario area in Macedonia, northern Greece. Chemie der Erde 58: 80-97.

O'Connor, P.J., Aftalion, M. \& Kennan, P.S., 1989. Isotopic U-Pb ages of zircon and monazite from the Leinster Granite, Southeast Ireland. Geological Magazine 126: 725-728.

Pesquera, A. \& Velasco, F., 1997. Mineralogy, geochemistry and geological significance of tourmaline-rich rocks from the Paleozoic Cinco Villas Massif (western Pyrenees, Spain). Contributions to Mineralogy and Petrology 129: 53-74.

Pharaoh, T.C., Merriman, R. J., Evans, J. A., Brewer, T.S., Webb, P.C. \& Smith, N.J.P., 1991. Early Palaeozoic arc-related volcanism in the Concealed Caledonides of Southern Britain. Annales de la Société géologique de Belgique 114: 63-91.

Slack, J. F., Palmer, M.R., Stevens, B.P. \& Barnes, R.G., 1993. Origin and significance of tourmaline-rich rocks in the Broken Hill District, Australia. Economic Geology 88: 505-541.

Slack, J.F., Passchier, C.W. \& Zhang, J.S., 1996. Metasomatic tourmalinite formation along basement-cover decollements, Orobic Alps, Italy. Schweizerische Mineralogische und Petrographische Mitteilungen 76: 193-207.

Stainier, X., 1889. Caillou tourmalinifère dans le poudingue de Burnot. Annales de la Société géologique de Belgique 17: 45-48.

Steemans, P., 1989. Paléogéographie de l' Eodévonien Ardennais et des régions limitrophes. Annales de la Société géologique de Belgique $112(1)$ : 103-119.
Steven, N.M. \& Moore, J.M., 1995. Tourmalinite mineralization in the Late Proterozoic Kuiseb Formation of the Damara Orogen, Central Namibia: Evidence for a replacement origin. Economic Geology 90: 1098-1117.

Sun, S.S. \& McDonough, W.F., 1989. Chemical And Isotopic Systematics Of Oceanic Basalts: Implications For Mantle Compositions And Processes. In: Saunders, A.D. \& Norry, M.J. (eds.): Magmatism In The Ocean Basins. Geological Society Special Publication (London) 42: 313-345.

Ziegler, P., 1982. Geological Atlas of Western and Central Europe. Shell Internationale Petroleum Maatschappij B.V., Elsevier (Amsterdam): $130 \mathrm{pp} \&$ enclosures.

\section{Appendix}

Petrographic classification of samples in text and Figures

\section{Lower Devonian samples:}

FO.1: Hydrothermal brecciated tourmalinite from the Fooz Formation

$B C .1$ : Hydrothermal brecciated tourmalinite from the Burnot Formation

BC.2: Banded poikiloblastic tourmalinite from the Burnot Formation

\section{Middle Devonian samples:}

$V E .3, V M .6 b$ : Very fine grained banded tourmalinites from the Vicht Formation

$V M .1 a, V M .4, V P .4$ : Very fine grained tourmalinites from the Vicht Formation

VM.5: Medium grained banded tourmalinite from the Vicht Formation

$P G M .2 a$ : Very fine grained banded tourmalinite from the Pépinster Formation

TLC.2a: Very fine grained tourmalinite from the Rivière Formation

TLC. 4a: Partly poikiloblastic, partly medium grained tourmalinite from the Rivière Formation 